\title{
Rumen protein degradation and biosynthesis
}

\section{A new method for determination of protein degradation in rumen fluid in vitro}

\author{
BY L. RAAB, B. CAFANTARIS, T. JILG AND K. H. MENKE* \\ Institute of Animal Nutrition, University of Hohenheim, Emil-Wolff-Strasse 10, \\ 7000 Stuttgart 70, Federal Republic of Germany
}

(Received 7 February 1983 - Accepted 13 May 1983)

1. A method is described for the determination of protein degradation based on measurements of ammonia concentration and gas production (Menke et al. 1979) when a feedingstuff was incubated with rumen fluid in vitro.

2. $\mathrm{NH}_{3}$ liberated during incubation is in part used for microbial protein synthesis. Production of carbon dioxide and methane can be regarded as a measure of energy available for protein synthesis. The ratio, gas production: incorporation of $\mathrm{NH}_{3}$-nitrogen was estimated by addition of starch to the substrate. The response in gas production was linear in the range 0-200 mg starch, when starch was added to 0-200 mg feedingstuff dry matter and $30 \mathrm{ml}$ rumen fluid-medium mixture.

3. Linear regression between $\mathrm{NH}_{3}-\mathrm{N}$ concentration $(y, \mathrm{mg})$ and gas production $(x, \mathrm{ml})$ yielded an intercept $\left(b_{0}\right)$ representing that amount of $\mathrm{NH}_{3}-\mathrm{N}$ which would be released when no fermentable carbohydrates were available and consequently no bacterial protein synthesis took place.

4. The difference between this intercept $b_{0}$ and $\mathrm{NH}_{3}-\mathrm{N}$ content in the blank (rumen fluid without substrate added) indicated the amount of $\mathrm{NH}_{3}$ liberated from protein and other $\mathrm{N}$-containing compounds of the feedingstuff incubated. In vitro-degradable $\mathrm{N}$ (IVDN) was calculated as a proportion of total $\mathrm{N}$ by the equation:

$$
\text { IVDN }=\frac{\mathrm{NH}_{3}-\mathrm{N} \text { at zero gas production }\left(b_{\mathrm{o}}-\mathrm{NH}_{3}-\mathrm{N}\right. \text { of blank }}{\text { Total } \mathrm{N} \text { of feedingstuff incubated }}
$$

Degradability of protein in the rumen is an important value to be used for the prediction of protein passing undegraded to the small intestine and for the calculation of protein utilization and protein requirements of ruminants. Attempts have been made to estimate protein degradation from solubility tests (Crooker et al. 1978; Jarrige et al. 1978; Chamberlain \& Thomas, 1979) or by the use of polyester bags to be incubated in the rumen of a fistulated animal (Ørskov \& Mehrez, 1977). Difficulties in measuring protein degradation from the release of ammonia (Chamberlain \& Thomas, 1979) arise from the fact that protein degradation and bacterial protein synthesis are processes which occur simultaneously.

For separate determination of bacterial protein synthesis either certain characteristic constituents of micro-organisms such as diaminopimelic acid, RNA or DNA (Ling \& Buttery, 1978; Siddons et al. 1979), or isotopes such as ${ }^{35} \mathrm{~S},{ }^{32} \mathrm{P}$ or ${ }^{15} \mathrm{~N}$ can be used (Pilgrim et al. 1970; Hume, 1975; Walker \& Nader, 1975; McMeniman et al. 1976; Van Nevel \& Demeyer, 1977).

The method described here uses the known relationship between fermentation of carbohydrates and microbial protein synthesis for the determination of $\mathrm{NH}_{3}-\mathrm{N}$ incorporated into microbial proteins. The total amount of $\mathrm{NH}_{3}-\mathrm{N}$ liberated is found by extrapolation of the linear regression to zero protein synthesis.

\section{EXPERIMENTAL}

\section{Material and methods}

Incubations were carried out in $100-\mathrm{ml}$ calibrated syringes, according to the method described by Menke et al. (1979). Two rotating holders each capable of supporting fifty-eight syringes were used and positioned in ventilated drying ovens at $39^{\circ}$ (accuracy $0.5^{\circ}$ ).

Protein sources to be incubated were analysed for crude protein $(\mathrm{N} \times 6.25)$ and dry matter 
Table 1. Expts 1 and 2. Crude protein (nitrogen $\times 6 \cdot 25)$ content of feedingstuff, sample weight and amount of starch added

\begin{tabular}{|c|c|c|c|c|c|c|c|c|}
\hline $\begin{array}{l}\text { Expt } \\
\text { no. }\end{array}$ & \multirow{2}{*}{$\begin{array}{l}\text { Feedingstuff } \\
\text { Casein } \\
\text { Soya-bean meal } \\
\text { Rape-seed meal } \\
\text { Hay } \\
\text { Feather meal }\end{array}$} & $\frac{\begin{array}{c}\text { Crude } \\
\text { protein } \\
(\mathrm{g} / \mathrm{kg} \mathrm{DM})\end{array}}{921}$ & $\frac{\begin{array}{c}\text { Sample } \\
\text { wt* }^{*} \\
(\mathrm{mg} \mathrm{DM})\end{array}}{28 \cdot 2}$ & \multicolumn{5}{|c|}{$\begin{array}{l}\text { Amount of rice starch } \\
(\mathrm{mg}) \text { added } \\
(895 \mathrm{~g} \mathrm{DM} / \mathrm{kg})\end{array}$} \\
\hline 1 & & $\begin{array}{l}921 \\
487 \\
389 \\
134 \\
980\end{array}$ & $\begin{array}{r}28 \cdot 2 \\
55 \cdot 4 \\
68 \cdot 4 \\
194 \cdot 0 \\
26 \cdot 5\end{array}$ & $\begin{array}{l}50 \\
50 \\
50 \\
50 \\
50\end{array}$ & $\begin{array}{l}100 \\
100 \\
100 \\
100 \\
100\end{array}$ & $\begin{array}{l}150 \\
150 \\
150 \\
150 \\
150\end{array}$ & $\begin{array}{l}200 \\
200 \\
200 \\
200 \\
200\end{array}$ & $\begin{array}{l}250 \\
250 \\
250 \\
- \\
-\end{array}$ \\
\hline 2 & $\begin{array}{l}\text { Casein } \\
\text { Linseed-cake meal } \\
\text { Kapok residue } \\
\text { Hay } \\
\text { Maize-gluten feed }\end{array}$ & $\begin{array}{l}921 \\
330 \\
275 \\
134 \\
227\end{array}$ & $\begin{array}{r}28 \cdot 2 \\
80 \cdot 0 \\
94 \cdot 5 \\
194 \cdot 0 \\
114.5\end{array}$ & $\begin{array}{l}50 \\
50 \\
50 \\
50 \\
50\end{array}$ & $\begin{array}{l}100 \\
100 \\
100 \\
100 \\
100\end{array}$ & $\begin{array}{l}150 \\
150 \\
150 \\
150 \\
150\end{array}$ & $\begin{array}{l}200 \\
200 \\
200 \\
200 \\
200\end{array}$ & $\begin{array}{l}250 \\
250 \\
250 \\
- \\
-\end{array}$ \\
\hline
\end{tabular}

DM, dry matter.

* Sample weights containing $26 \mathrm{mg}$ crude protein.

(DM). In all experiments sample weight was chosen such that it corresponded to $26 \mathrm{mg}$ crude protein (e.g. $130 \mathrm{~g}$ crude protein $/ \mathrm{kg}$ in $200 \mathrm{mg} \mathrm{DM}$ ). This material and appropriate amounts of starch or other carbohydrates were first introduced into a syringe.

Rumen fluid was drawn from a rumen-cannulated dairy cow, receiving $2.6 \mathrm{~kg}$ hay, $3.3 \mathrm{~kg}$ barley, $0.6 \mathrm{~kg}$ soya-bean meal and $70 \mathrm{~g}$ of a mixture of minerals and vitamins. The ration was adjusted to the requirement of the cow without changing these proportions. Rumen fluid was withdrawn in the morning before feeding and filtered through two layers of cheese cloth into a warm flask of approximately 21 volume filled with carbon dioxide. Rumen fluid was mixed with two parts of a medium (for details of composition, see Menke et al. 1979) and the mixture dispensed in $30 \mathrm{ml}$ portions to the syringes, using a $\mathrm{CO}_{2}$ stream to maintain anaerobic conditions.

At the end of incubation the amount of gas produced was determined by reading the position of the plug (accuracy $0.5 \mathrm{ml}$ ). Then the syringe was put into an ice-bath at $0^{\circ}$ in order to prevent further microbial activity. The contents of the syringes were transferred quantitatively to Kjeldahl flasks for determination of $\mathrm{NH}_{3}$ by distillation with magnesium oxide, according to Bremner (1965). Liberated $\mathrm{NH}_{3}$ was trapped in 2-3 ml 0.2 M-sulphuric acid and titrated with $0 \cdot 1 \mathrm{M}$-sodium hydroxide.

All incubations were run in duplicate (Expts 1,2 and 4) or triplicate (Expts 3 and 5). In addition, three syringes with rumen fluid-medium mixture were incubated as blanks. Incubations with rumen fluid from different days were repeated with some of the protein sources.

Expt 1

The following feedingstuffs were used to study the effects of increasing amounts of rice starch on gas production and $\mathrm{NH}_{3}-\mathrm{N}$ concentration during fermentation: casein, extracted soya-bean meal, extracted rape-seed meal, hay and non-hydrolysed feather meal.

\section{Expt 2}

Casein and hay were studied again in this experiment; in addition linseed-cake meal, kapok residues and maize-gluten feed were also used (Table 1). 
Table 2. Expt 4. Composition ( $\mathrm{g} / \mathrm{kg}$ on a dry matter (DM) basis), crude protein (nitrogen $\times 6.25$ ) content and sample weights of rations tested

(Amounts of starch added were always 30, 60 and $90 \mathrm{mg}$ air-DM)

\begin{tabular}{lrrrrr}
\hline \hline Ration & 1 & $2^{*}$ & 3 & 4 & 5 \\
\hline Maize silage $\dagger$ & 325 & 325 & 430 & 430 & 430 \\
Hay & 165 & 165 & 210 & 210 & 210 \\
Concentrate & 500 & 500 & 360 & 360 & 360 \\
Mineral feed & 10 & 10 & - & - & - \\
Crude protein & 149 & 153 & 138 & 138 & 102 \\
NPN: N value & 0 & 0 & 0 & $0 \cdot 26$ & 0 \\
Sample weight (mg DM) & 174 & 170 & 188 & 188 & 255 \\
\hline
\end{tabular}

NPN, non-protein-N.

* Containing formaldehyde-treated soya-bean protein.

$\dagger$ Dried material $\left(60^{\circ}\right)$ was used for in vitro incubation.

Whole diets were incubated.

\section{Expt 3}

Pectin, inulin, xylan, sorbitol, glucose, cellobiose, cellulose (chemically pure) and unpurified cellulose (toilet paper) were used, alone or in combinations, in place of maize starch to compare the effects on in vitro-degradable $\mathrm{N}$ (IVDN) determination of casein, extracted soya-bean meal and artificially-dried grass (Table 6, see p. 575).

\section{Expt 4}

Five rations, previously tested in studies with cannulated dairy cows at the Agricultural Research Station in Braunschweig (FAL), were taken for comparison with the in vitro method described. In vivo degradability of protein was measured using ${ }^{15} \mathrm{~N}$ (Brandt \& Rohr, 1981). The compositions of the rations are given in Table 2. In ration 2 half the protein was formaldehyde-treated soya-bean protein. Ration 1 was similar in composition but with untreated soya-bean protein. Ration 4 differed from ration 5 in having a supplement of urea, bringing the crude protein content to $138 \mathrm{~g} / \mathrm{kg}$, compared with $102 \mathrm{~g} / \mathrm{kg}$ in ration 5 . All rations were incubated for 8 and $24 \mathrm{~h}$. Ration 2 was additionally tested at $6,12,15$ and $17 \mathrm{~h}$ of incubation.

\section{Expt 5}

The effect of period of incubation on starch fermentation, $\mathrm{pH}$ and volatile fatty acid (VFA) production as well as the composition of the gas phase after $8 \mathrm{~h}$ incubation was investigated here.

The relationship between starch fermentation and gas production has been studied by incubation of constant amounts of rice starch $(180 \mathrm{mg} D M)$ for different periods of incubation. For determination of residual starch, the rumen fluid was adjusted to $\mathrm{pH} 4.8$ with acetate buffer and incubated with $50 \mathrm{mg}$ amyloglucosidase (EC 3.2.1.3) for $22 \mathrm{~h}$ (Salewski et al. 1974). The glucose formed was determined by the method of Luff-Schoorl (Naumann et al. 1976).

Immediately after addition of starch and subsequent cooling of the rumen fluid, $99 \%$ of the starch added was recovered. Incubations were stopped after $1 \cdot 5,3 \cdot 0,4 \cdot 5,6 \cdot 0,7 \cdot 5$ and $8 \mathrm{~h}$ to measure gas production and determine residual starch.

Changes in $\mathrm{pH}$ and composition of the VFA fraction were studied in a separate experiment, in which $150 \mathrm{mg}$ starch and $8.9 \mathrm{mg}$ urea were incubated as indicated in Table 8 (see p. 577). The composition of gas in the syringes was analysed after an $8 \mathrm{~h}$ incubation 


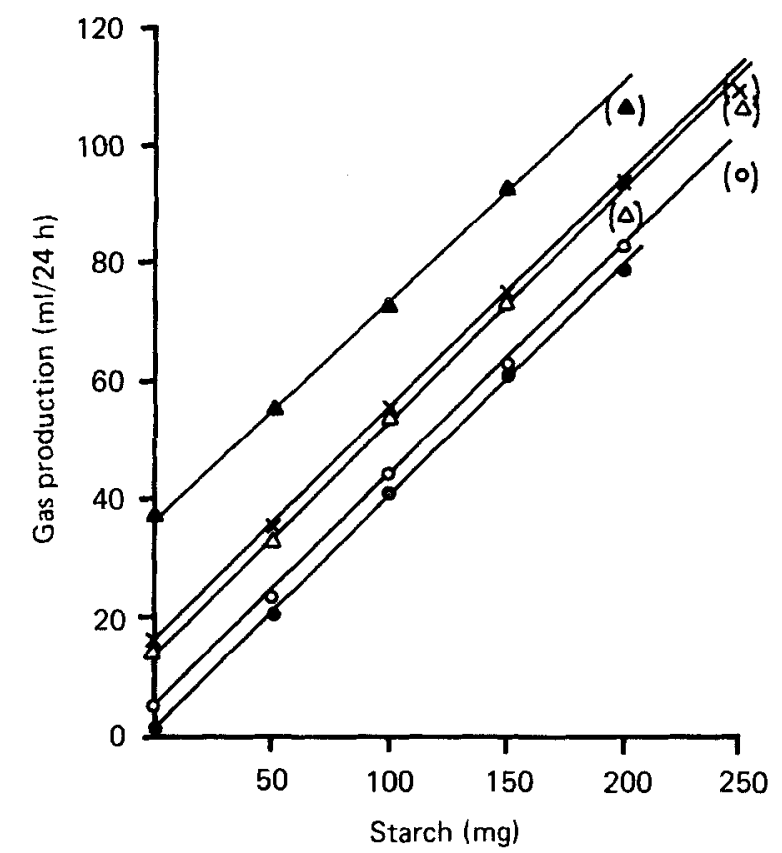

Fig. 1. Expt 1. Gas production ( $\mathrm{ml} / 24 \mathrm{~h})$ in vitro with different amounts of starch (mg) added. Regression equations:

Casein
Soya-bean meal
Rape-seed meal
Hay
Feather meal

$\begin{array}{lll}\text { (O) } & y=5.10+0.3935 x & 0.9994 \\ (\triangle) & y=13.83+0.4050 x & 0.9991 \\ \text { (x) } & y=16.15+0.3945 x & 0.9997 \\ \text { (A) } y=36.53+0.3800 x & 0.9946 \\ \text { (C) } y=1.70+0.3965 x & 0.9994\end{array}$

period. VFA, $\mathrm{CO}_{2}$, methane and hydrogen were determined using a Hewlett-Packard gas-liquid chromatograph (for details of procedures, see Cafantaris, 1981).

\section{Estimates of protein degradability}

Estimates were calculated from appropriate linear regressions of $\mathrm{NH}_{3}-\mathrm{N}$ concentration $(y, \mathrm{mg}) v$. gas production $(x, \mathrm{ml})$. The intercept $b_{0}$ represented that amount of $\mathrm{NH}_{3}-\mathrm{N}$ which would be released when no fermentable carbohydrates were available and consequently no bacterial protein synthesis took place. The difference between this intercept $b_{0}$ and $\mathrm{NH}_{3}-\mathrm{N}$ content in the blank (rumen fluid without substrate added) indicated the amount of $\mathrm{NH}_{3}$ liberated from protein and other $\mathrm{N}$-containing compounds of the feedingstuff incubated. IVDN was calculated as a proportion of total $\mathrm{N}$ by the equation:

$$
\text { IVDN }=\frac{\mathrm{NH}_{3}-\mathrm{N} \text { at zero gas production }\left(b_{\mathrm{o}}\right)-\mathrm{NH}_{3}-\mathrm{N} \text { of blank }}{\text { total } \mathrm{N} \text { of feedingstuff incubated }}
$$

The period of incubation adopted was generally $24 \mathrm{~h}$. When different incubation periods (h) were used this is indicated by a subscript (e.g. IVDN ${ }_{8}$ ).

\section{RESULTS}

\section{Expts 1 and 2}

With all feedingstuffs tested a linear increase in gas production was observed with increasing amounts of added starch (Figs. 1 and 2). The regression equations differed in their intercepts but had almost the same regression coefficients (approximately $0.39 \mathrm{ml}$ gas $/ \mathrm{mg}$ starch 


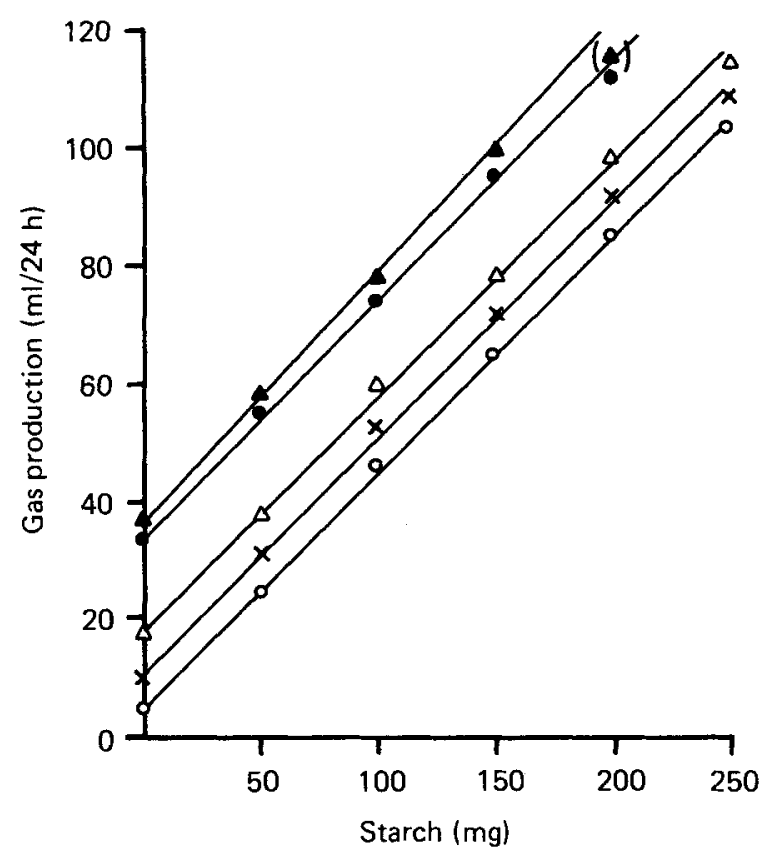

Fig. 2. Expt 2. Gas production ( $\mathrm{ml} / 24 \mathrm{~h}$ ) in vitro with different amounts of starch (mg) added. Regression equations:

$\begin{array}{lllc} & & & R \\ \text { Casein } & \text { (O) } & y=5.92+0.3940 x & 0.9996 \\ \text { Linseed-cake meal } & (\triangle) & y=20.19+0.3869 x & 0.9983 \\ \text { Kapok residue } & \text { (x) } y=11.99+0.3940 x & 0.9994 \\ \text { Hay } & \text { (A) } y=37.41+0.4214 x & 0.9978 \\ \text { Maize-gluten feed } & \text { (O) } y=34.60+0.4000 x & 0.9954\end{array}$

added). Only when gas production rates were greater than $90 \mathrm{ml} / 24 \mathrm{~h}$ did lower increments occur. These values were omitted when calculating the regression equations.

$\mathrm{NH}_{3}-\mathrm{N}$ contents measured after $24 \mathrm{~h}$ incubation decreased with increasing amounts of added starch. Again the intercepts were different between the feedingstuffs incubated, indicating differences in the degradability of the protein (Table 3). Regression coefficients also differed between feedingstuffs. For all feedingstuffs tested (except hay, which could be tested with three levels of starch only) linear regression equations were highly significant. The same was true for the relationship between gas production and $\mathrm{NH}_{3}-\mathrm{N}$ content after 24 h (Table 4).

Mean (with SEM) values for blanks $(n 3)$ were $4.68(0.05)$ and $5.93(0.09) \mathrm{mg} \mathrm{NH}_{3}-\mathrm{N}$ in Expts 1 and 2 respectively. Subtraction of these blanks from the intercepts of regression equations in Table 4, and division of the difference by the total amount of $\mathrm{N}$ in the feedingstuff $(4.16 \mathrm{mg})$ gave the IVDN values shown in Table 5. Expts 1 and 2 have in part been repeated with incubation periods of $12 \mathrm{~h}$. The results are included in Table 5.

\section{Expt 3}

When starch is used as an energy source for bacterial protein synthesis, the assumption is made that gas production is a measure of energy available for protein synthesis, independent of the kind of carbohydrate fermented. Differences in fermentation pattern(VFA production) may, however, cause different ATP: $\mathrm{CO}_{2}$ production values, and these may be reflected in the regression lines between gas production and $\mathrm{NH}_{3}-\mathrm{N}$ utilization.

In Expt 3 maize starch was replaced by some other carbohydrates in IVDN determinations. 
Table 3. Regression equations (with standard errors of intercepts and regression coefficients in parentheses) showing the effect of the amount of starch added $(\mathrm{x}, \mathrm{mg})$ on ammonia-nitrogen content of rumen fluid after $24 \mathrm{~h}$ incubation $(\mathrm{y}, \mathrm{mg})$

\begin{tabular}{clcrrr}
\hline Expt no. & Feedingstuff & Regression equation & \multicolumn{1}{c}{$n$} & $R$ \\
\hline 1 & Casein & $y=8.542(0.0405)-0.0230(0.0006) x$ & 10 & -0.997 \\
& Soya-bean meal & $y=7.955(0.0520)-0.0220(0.0007) x$ & 8 & -0.995 \\
& Rape-seed meal & $y=7.322(0.0159)-0.0205(0.0002) x$ & 10 & -0.999 \\
& Hay & $y=4.499(0.0903)-0.0189(0.0023) x$ & 6 & -0.972 \\
& Feather meal & $y=5.299(0.0409)-0.0186(0.0007) x$ & 8 & -0.996 \\
2 & Casein & $y=9.948(0.0486)-0.0181(0.0006) x$ & 11 & -0.995 \\
& Linseed-cake meal & $y=8.712(0.0564)-0.0146(0.0009) x$ & 8 & -0.986 \\
& Kapok residue & $y=8.318(0.0465)-0.0156(0.0006) x$ & 11 & -0.994 \\
& Hay & $y=6.084(0.0412)-0.0152(0.0009) x$ & 7 & -0.990 \\
& Maize-gluten feed & $y=7.049(0.0477)-0.0162(0.0010) x$ & 5 & -0.991 \\
\hline
\end{tabular}

Table 4. Regression equations (with standard errors of intercepts and regression coefficients in parentheses) showing the relationship between gas production $(\mathrm{x}, \mathrm{ml} / 24 \mathrm{~h})$ and ammonianitrogen content of rumen fluid after $24 \mathrm{~h}$ incubation $(\mathrm{y}, \mathrm{mg})$

\begin{tabular}{cllrrr}
\hline Expt no. & Feedingstuff & Regression equation & $n$ & $R$ \\
\hline 1 & Casein & $y=8.80(0.062)-0.0573(0.0024) x$ & 10 & -0.993 \\
& Soya-bean meal & $y=8.61(0.048)-0.0510(0.0023) x$ & 8 & -0.994 \\
& Rape-seed meal & $y=8.19(0.030)-0.0526(0.0012) x$ & 10 & -0.998 \\
& Hay & $y=6.26(0.108)-0.0491(0.0068) x$ & 6 & -0.963 \\
& Feather meal & $y=5.38(0.040)-0.0468(0.0016) x$ & 8 & -0.996 \\
2 & Casein & $y=10.22(0.057)-0.0458(0.0018) x$ & 11 & -0.993 \\
& Linseed-cake meal & $y=9.48(0.053)-0.0387(0.0018) x$ & 8 & -0.994 \\
& Kapok residue & $y=8.79(0.052)-0.0395(0.0016) x$ & 11 & -0.993 \\
& Hay & $y=7.41(0.067)-0.0356(0.0031) x$ & 7 & -0.982 \\
& Maize-gluten feed & $y=8.58(0.014)-0.0432(0.0008) x$ & 5 & -0.999 \\
\hline
\end{tabular}

Table 5. Expts 1 and 2. In vitro-degradable nitrogen (proportion of total $N$ )* after $12 \mathrm{~h}$ $\left(I V D N_{12}\right)$ and $24 h\left(I V D N_{24}\right)$ of incubation

\begin{tabular}{clcccccc}
\hline $\begin{array}{c}\text { Expt } \\
\text { no. }\end{array}$ & Feedingstuff & IVDN $_{12}$ & IVDN $_{24}$ & $\begin{array}{c}\text { Expt } \\
\text { no. }\end{array}$ & Feedingstuff & IVDN $_{12}$ & IVDN $_{24}$ \\
\hline 1 & Casein & 0.86 & 0.99 & 2 & Casein & - & 1.03 \\
& Soya-been meal & 0.78 & 0.94 & & Linseed meal & 0.72 & 0.85 \\
& Rape-seed meal & 0.71 & 0.84 & & Kapok residue & - & 0.69 \\
& Hay & - & 0.38 & & Hay & - & 0.36 \\
& Feather meal & - & 0.17 & & Maize-gluten feed & 43 & 0.64 \\
\hline
\end{tabular}

* $\mathrm{NH}_{3}-\mathrm{N}$ at zero gas production $\left(b_{0}\right)-\mathrm{NH}_{3}-\mathrm{N}$ of blank

Total $\mathrm{N}$ of feedingstuff incubated 


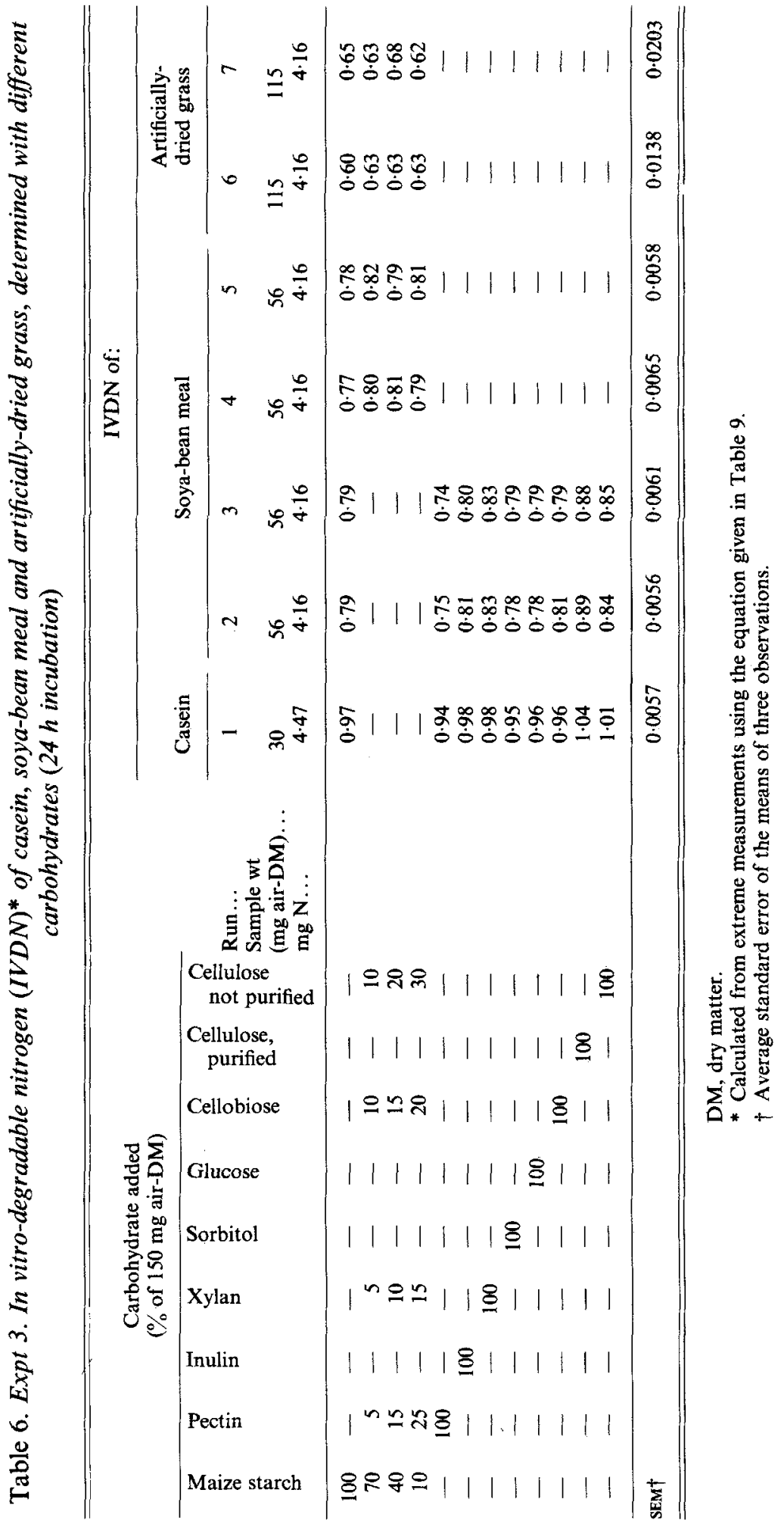


Table 7. Expt 4. Comparison of in vitro-degradable nitrogen (IVDN), determined after different incubation times (h) shown as subscripts, with rations previously tested in ${ }^{15} \mathrm{~N}$ experiments with cannulated dairy cows, from which rumen degradability (RDN) has been calculated (Brandt, 1979; Brandt et al. 1981)*

\begin{tabular}{ccccccccc}
\hline \hline $\begin{array}{c}\text { Ration } \\
\text { no. }\end{array}$ & IVDN $_{\mathbf{6}}$ & IVDN $_{8}$ & IVDN $_{\mathbf{1 2}}$ & IVDN $_{15}$ & IVDN $_{17}$ & IVDN $_{24}$ & RDN* $^{*}$ \\
\hline 1 & - & 0.67 & - & - & - & 0.76 & $0.78 \dagger$ & 0.78 \\
2 & 0.41 & 0.49 & 0.51 & 0.54 & 0.66 & 0.83 & - & 0.64 \\
3 & - & 0.67 & - & - & - & 0.86 & $0.87 \dagger$ & 0.82 \\
4 & - & 0.55 & - & - & - & 0.72 & $0.65 \dagger$ & 0.74 \\
5 & - & 0.74 & - & - & - & 0.74 & $0.75 \dagger$ & 0.76 \\
\hline \hline
\end{tabular}

* ${ }^{15} \mathrm{~N}$-labelled urea was infused continuously into the rumen during the first $4 \mathrm{~d}$ of a 5 -d digesta sampling period. ${ }^{15} \mathrm{~N}$-excess was measured in bacterial and protozoal $\mathrm{N}$ isolated from duodenal digesta and rumen fluid, in non-ammonia- $\mathrm{N}$ of duodenal digesta and in milk (as an estimate of ${ }^{15} \mathrm{~N}$-excess in endogenous protein from postruminal secretion). Undegraded dietary $\mathrm{N}$ was calculated from microbial $\mathrm{N}$ and non- $\mathrm{NH}_{3}-\mathrm{N}$ at the duodenum, corrected for endogenous $\mathrm{N}$.

$\dagger$ Repeated with different rumen fluid.

The results in Table 6 show lower IVDN estimates with pectin and higher values with xylan and cellulose when these were added in amounts of $150 \mathrm{mg}$ to soya-bean meal $(56 \mathrm{mg})$. No other carbohydrates (inulin, sorbitol, glucose, cellobiose) were different from starch in their effects on IVDN. With casein, only the effects of cellulose and inulin were significantly different from starch. Mixtures of 700,400 and $100 \mathrm{~g}$ starch $/ \mathrm{kg}$ with 300,600 and $900 \mathrm{~g}$ of other carbohydrates (pectin, xylan, cellobiose and unpurified cellulose) $/ \mathrm{kg}$ resulted in higher IVDN estimates of casein, soya-bean meal and artificially-dried grass, compared with those produced with starch. The different proportions of starch in these carbohydrate mixtures seemed to have no effect on IVDN. There appeared to be a marked difference in the effects of chemically-purified and unpurified cellulose, the latter being more-readily fermented and causing lower IVDN values.

\section{Expt 4}

The results of in vitro incubations with rations previously tested in ${ }^{15} \mathrm{~N}$ experiments with cannulated dairy cows are shown in Table 7 and compared with protein degradabilities obtained in vivo. In the first trial, these rations were tested in a $24 \mathrm{~h}$ incubation period. The results show fairly good agreement with the in vivo values for rations $1,3,4$ and 5 . In order to find an explanation for the difference found between these two methods when applied to ration 2, which contained protected protein, all rations were tested in an $8 \mathrm{~h}$ incubation period. In addition, samples of ration 2 were incubated for $6,12,15$ and $17 \mathrm{~h}$. The results are included in Table 7 and demonstrate that protection of protein is efficient up to $15 \mathrm{~h}$ of incubation but seems to be destroyed thereafter. Therefore, protein degradation after $24 \mathrm{~h}$ is as high in ration 2 as in ration 1 , which contained untreated soyabean protein. More than $80 \%$ of non-protected protein degraded within $24 \mathrm{~h}$ was degraded in the first $8 \mathrm{~h}$.

\section{Expt 5}

The results of Expt 4 indicated that it may become necessary to study degradability of protein for different periods of incubation. Therefore, an experiment was set up in which disappearance of starch was measured for different periods of incubation. As can be seen from Fig. 3, a decrease in starch content in the rumen fluid was closely related to gas production, showing a small deviation from linearity in the first hours of incubation only. 


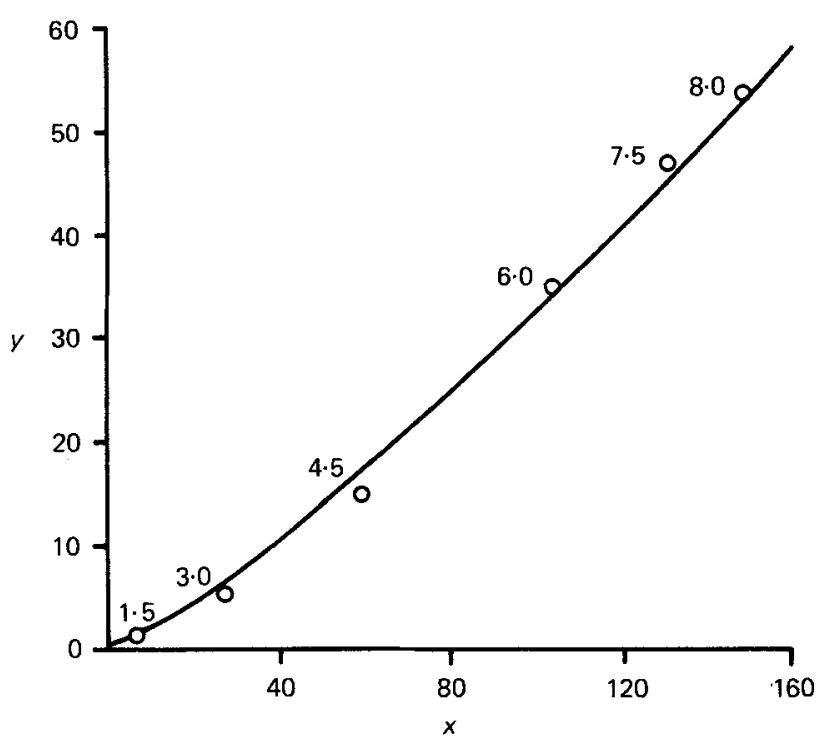

Fig. 3. Relationship between gas production $(y, \mathrm{ml} / 24 \mathrm{~h})$ and disappearance of $\operatorname{starch}(x, \mathrm{mg})$ during $1 \cdot 5,3 \cdot 0,4 \cdot 5,6 \cdot 0$ and $8 \cdot 0 \mathrm{~h}$ of incubation $(n 6)$.

$$
y=0.114 x^{1.233} ; R 0.999 ; \text { residual sD } 0.08 \text {. }
$$

Table 8. Effect of period of incubation on $p H$ and volatile fatty acids $(V F A)$ in rumen fluid, and composition of gas during studies on protein degradation (150 $\mathrm{mg}$ starch and $8.9 \mathrm{mg}$ urea)

\begin{tabular}{|c|c|c|c|c|c|c|}
\hline Period of incubation (h)... & 4 & 6 & 8 & 10 & 12 & SEM $^{*}$ \\
\hline $\mathrm{pH}$ & - & - & 6.69 & 6.61 & 6.56 & 0.02 \\
\hline Gas production (ml) & $22 \cdot 0$ & 44.5 & $53 \cdot 1$ & $57 \cdot 3$ & - & $1 \cdot 11$ \\
\hline VFA production ( $(\mathrm{mol})$ & 428 & 743 & 817 & 917 & - & 51 \\
\hline Acetate $(\mathrm{mmol} / \mathrm{mol})$ & 710 & 635 & 649 & 660 & - & 12 \\
\hline Propionate $(\mathrm{mmol} / \mathrm{mol})$ & 209 & 220 & 206 & 210 & 一 & 5 \\
\hline Butyrate $(\mathrm{mmol} / \mathrm{mol})$ & 81 & 146 & 145 & 130 & - & 11 \\
\hline Gas production ( $\mu \mathrm{mol})$ & - & - & 1775 & - & - & 20 \\
\hline $\begin{array}{l}\text { Carbon dioxide } \\
\text { (\% total gas production) }\end{array}$ & - & - & 83.9 & - & - & 0.6 \\
\hline Methane (\% total gas production) & - & - & $16 \cdot 1$ & - & - & 0.6 \\
\hline Hydrogen $(\%$ total gas production) & - & - & 0.02 & - & - & - \\
\hline
\end{tabular}

* Average standard error of the means of four to five observations.

Mean values for measurements of $\mathrm{pH}$ and VFA after 4-12 $\mathrm{h}$ incubation are given in Table 8. $\mathrm{pH}$ did not fall below 6.5 . VFA production was approximately $17 \mu \mathrm{mol} / \mathrm{ml}$ gas produced. Acetate, propionate and butyrate were present in normal proportions $(0 \cdot 6-0 \cdot 7,0 \cdot 2-0.22$ and $0.08-0.15$ respectively). In the first hours butyrate increased at the expense of acetate. Propionate proportions were fairly constant.

The gas phase of the syringes contained $\mathrm{CO}_{2}$ and methane in the proportions $0 \cdot 84: 0 \cdot 16$ after $8 \mathrm{~h}$ of incubation. Hydrogen occurred in very small amounts. 


\section{DISCUSSION}

\section{Relationships between gas production and disappearance of $\mathrm{NH}_{3}-\mathrm{N}$}

The results of Expts 1 and 2 demonstrated linearity between the amount of starch added and gas production on the one hand (Figs. 1 and 2) and a decrease in $\mathrm{NH}_{3}-\mathrm{N}$ in rumen fluid on the other (Table 3). Consequently, the relationship between gas production and decrease in $\mathrm{NH}_{3}-\mathrm{N}$ was linear also (Table 4). Deviations from linearity appeared with gas production rates of more than $90 \mathrm{ml} / 24 \mathrm{~h}$, which corresponded to $200 \mathrm{mg}$ starch added to 30-100 $\mathrm{mg}$ feedingstufi (DM basis) when the feedingstuff was high in protein (e.g. soya-bean meal, rape-seed meal) or the addition of $150 \mathrm{mg}$ starch to $100-200 \mathrm{mg}$ feedingstuff with less than $250 \mathrm{~g}$ crude protein $/ \mathrm{kg}$ (e.g. hay, maize-gluten). The amount of protein incubated should be more than $20 \mathrm{mg}$ in order to obtain reliable results. This may lead to rather high sample weights with feedingstuffs low in protein and to smaller ranges for the calculation of regression lines. It is to be expected, therefore, that IVDN values of those feedingstuffs will have higher standard deviations.

\section{Effect of rumen fluid}

Regression coefficients in Figs. 1 and 2 showed closely similar relationships between starch fermentation and gas production, irrespective of feedingstuff incubated. There were differences in regression coefficients in Tables 3 and 4, however, indicating effects of both rumen fluid and feedingstuff incubated on the disappearance of $\mathrm{NH}_{3}-\mathrm{N}$ per unit carbohydrate fermented. The latter value was related to the efficiency of energy utilization for microbial protein synthesis, expressed as $\mathrm{mg}$ microbial $\mathrm{N}$ synthesized per $\mathrm{g}$ truly-digestible organic matter (MN/TDOM) or $\because \mathrm{g}$ microbial DM synthesized per mmol ATP $\left(Y_{\mathrm{ATP}}\right)$. The regression coefficient for casein in Expt 1, for example, was 0.023 (sEM 0.0006) $\mathrm{mg} \mathrm{NH}_{3}-\mathrm{N} / \mathrm{mg}$ added starch, corresponding to $23 \mathrm{mg}$ microbial N/g TDOM (assuming starch to be $100 \%$ truly-digested) and $15.7 Y_{\text {ATP }}$ (calculated according to Hespell \& Bryant, 1979 and Harrison \& McAllan, 1980). In Expt 2 the regression coefficient for casein was significantly lower: 0.0181 (SEM 0.0006) $\mathrm{mg} \mathrm{NH}_{3}-\mathrm{N} / \mathrm{mg}$ added starch, corresponding to $18.1 \mathrm{mg} \mathrm{N} / \mathrm{g}$ TDOM and $12 \cdot 3 Y_{\text {ATP. }}$. In spite of this difference, there seemed to be no effect of rumen fluid on IVDN values of casein $(99,103)$ and hay $(38,36)$ calculated from these regression coefficients (Table 5). In other words, different slopes met at the same point on the $y$-axis. This was confirmed in Expt 3 where IVDN measurements of soya-bean meal were made with four different batches of rumen fluid in time intervals of 1-10 weeks (Table 6, runs 2-5). Taking account also of other values (K. H. Menke, L. Raab, B. Cafantaris, K. Matthes and T. Jilg, unpublished observations) the following mean (with SEM) values of IVDN $_{24}$ estimates with rumen fluid from different days $(n)$ were: casein $97.9(1 \cdot 1)(n 8)$, extracted soya-bean meal $90.9(0.7)(n 6)$, extracted rape-seed meal $78.9(1.3)(n 4)$, hay $37.8(1.2)$ (n 3). (Average SEM of five observations on gas production and $\mathrm{NH}_{3}$ concentration were $0.59 \mathrm{ml}$ gas and $0.026 \mathrm{mg} \mathrm{NH}_{3}-\mathrm{N}$; Cafantaris, 1981.)

Casein seemed to be the most sensitive indicator of rumen fluid quality with regard to IVDN determination but, when compared with gas production from standard feedingstuffs routinely used for in vitro digestibility studies (hay and starch; Menke et al. 1979), there was no significant change of IVDN when gas production of these standard feedingstuffs varied by up to $5 \%$. Lazger deviations in gas production, however, should not be used for correction of IVDN estimates, since different protein sources are affected to a different extent. They simply may indicate when a series has to be discarded. 


\section{Effects of carbohydrates other than starch}

The effects of different carbohydrates as energy sources in IVDN determinations have been studied in Expt 3. The results showed no significant difference in IVDN vaues when inulin, sorbitol, glucose or cellobiose was used in place of starch as an energy source (Table 6). Pectin caused somewhat lower, and cellulose higher, IVDN values than starch. Differences in microbial efficiency and in IVDN seem to be related to the rate of fermentation (ml gas $/ 24 \mathrm{~h}$ ). Gas production $(\mathrm{ml} / 24 \mathrm{~h}$ ) was particularly low with purified cellulose (40-42) comfared with starch (67-70) or pectin (73-75). The following equations have been found with $56 \mathrm{mg}$ soya-bean meal and $150 \mathrm{mg}$ of the different carbohydrates (Table 6, runs 2, 3, 4 and 5):

$$
\begin{array}{lll}
y_{1}=150.4-1.39 x ; & r-0.88 & n 26 \\
y_{2}=101.4-0.33 x ; & r-0.88 & n 26
\end{array}
$$

where $y_{1}$ is $\mathrm{NH}_{3}-\mathrm{N}$ disappearance $\left(\mu \mathrm{g} / \mathrm{ml}\right.$ gas produced) in $24 \mathrm{~h}, y_{\mathrm{s}}$ is $\operatorname{IVDN}_{24}(24 \mathrm{~h}$ incubation), $x$ is gas production $(\mathrm{ml})$ in $24 \mathrm{~h}$.

With casein (run 1) and artificially-dried grass (runs 6 and 7) similar correlations were found. This relationship cannot be explained by differences in gas production per $\mathrm{mg}$ carbohydrate. Steingass (1983) found identical gas production from starch and from purified cellulose, when corrected for residual carbohydrate not fermented during incubation. There was a difference, however, in the time-course of fermentation. Gas production from starch was high in the first $12 \mathrm{~h}$ of incubation but rather low thereafter, indicating a period of starvation and microbial lysis. Fermentation of purified cellulose was low in the first $8 \mathrm{~h}$ and increased at a constant rate without inclination to a saturation point within a $24 \mathrm{~h}$ period. The extent of microbial lysis, therefore, must be higher with easily-fermentable carbohydrates, when the time of incubation was longer than needed for a given amount of substrate (150 mg in Expt 3). $\mathrm{NH}_{3}-\mathrm{N}$ from microbial lysis was added to that $\mathrm{NH}_{3}-\mathrm{N}$ not utilized and would thus reduce microbial efficiency $\left(y_{1}\right)$. Again, the effect on IVDN $\left(y_{2}\right)$ was less pronounced, as can be seen from comparison of the regression coefficients $(1 \cdot 39 v .0 \cdot 33)$. For a discussion of the relationship between rate of fermentation, incubation time and the efficiency of energy utilization for microbial protein synthesis, see Raab (1980).

There were no significant differences in IVDN determined with mixtures $(\mathrm{g} / \mathrm{kg})$ in the range of 100-700 starch with 50-250 pectin, 50-150 xylan, 100-200 cellobiose and 100-300 unpurified cellulose (Table 6, runs 4-7). Incubations with pure starch resulted in approximately $2 \%$ lower IVDN values. The back projection of a line determined with starch would differ in this order of magnitude from that ratio caused by the carbohydrate of the feedingstuff, provided its composition was in the range of mixtures used in Expt 3. Further experiments would show whether this difference is constant for all feedingstuffs of interest, thus allowing an additive correction of values determined with starch.

Estimation of protein synthesis from $\mathrm{NH}_{3}-\mathrm{N}$ disappearance and gas production may include the utilization of amino acids and peptides for microbial protein synthesis, provided that the following assumptions are valid: (1) all preformed monomers are deaminated, when no gas production occurs in $24 \mathrm{~h}$ incubation; (2) there is a linear relationship between non-deaminated amino acids and gas production (see Fig. 4).

The first assumption is difficult to prove. Amino acids present after $24 \mathrm{~h}$ of starvation can be the result of microbial lysis and may not be due to incomplete deamination of amino acids deliberated from the protein of the feedingstuff added. The ratio of amino acids derived from microbial lysis to those deliberated from feed protein but not deaminated, may change with time of fermentation and amount of starch added. 


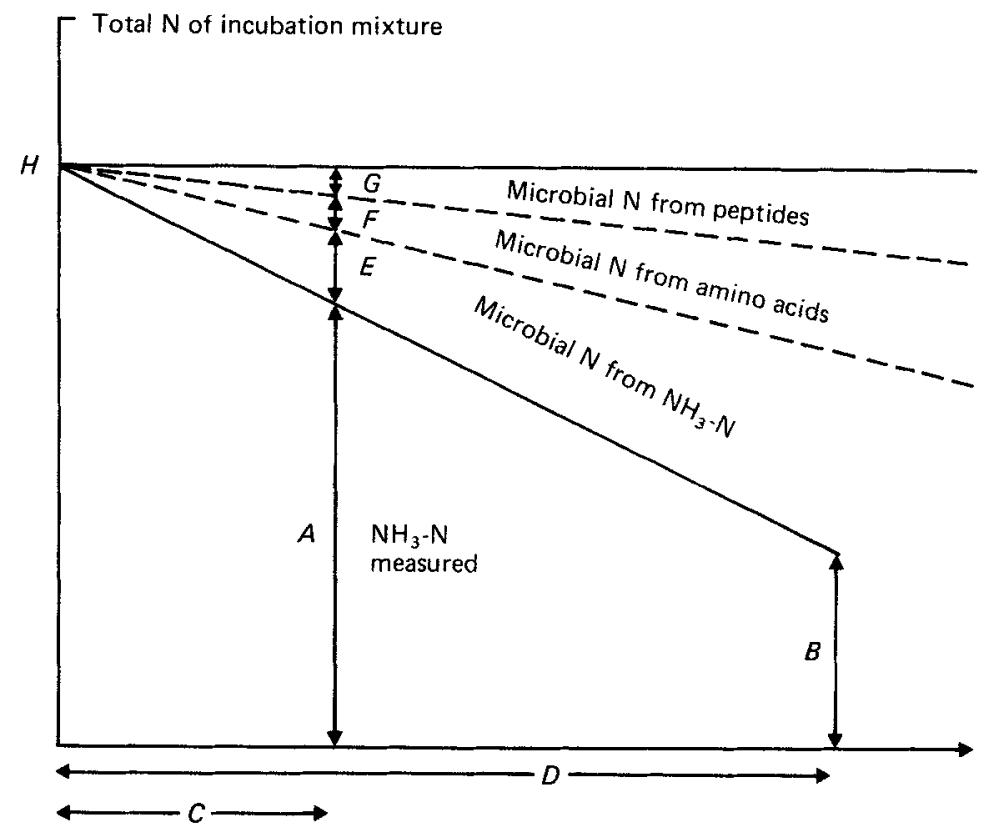

Fig. 4. Schematic representation of the relationship between protein degradation and protein synthesis in rumen fluid in vitro.

$A$, ammonia-nitrogen content after incubation of feedingstuff alone;

$B$, ammonia-nitrogen content after incubation of feedingstuff + starch;

$C$, gas production from feedingstuff alone;

$D$, gas productions from feedingstuff + starch;

$E, F, G$, microbial $\mathrm{N}$ expected to be derived from $\mathrm{NH}_{3}-\mathrm{N}$, amino acids and peptides, when the feedingstuff is incubated alone;

$H, \mathrm{NH}_{3}-\mathrm{N}$ expected to be present at zero gas production.

\section{Protein degradation and residence time in the rumen}

In vitro methods not only have the advantage of being less expensive and less timeconsuming, but also give the chance to maintain experimental conditions more precisely than in vivo trials permit. On the other hand, application of in vitro results to the prediction of in vivo events is dependent on how well the conditions are known of the in vivo event in question. Rumen degradability of protein, for example, is not only related to the kind of feedingstuff and nature of protein, but it is also a function of the residence time of the feedingstuff in the rumen. Ørskov \& McDonald (1979) determined the rate of passage of soya-bean meal (treated with sodium dichromate) in the rumen of sheep and corrected protein disappearance from polyester bags using an exponential equation. In this way they calculated different final degradabilities for restricted (0.71) and ad lib-fed animals $(0.66)$, which correspond to rumen incubation times of 12.5 and $10.5 \mathrm{~h}$ respectively. Mathers \& Miller (1981) derived incubation times of 7.6-11.2 h from their experiments with sheep given chopped lucerne (Medicago sativa) and rolled barley, using the same exponential equation as Ørskov \& McDonald (1979). Dilution rate of rumen fluid varied widely between sheep within diets, and individual animals showed no consistent trend across diets in these experiments. It seems even more difficult to derive a function from the many other experiments on mean retentions times in the rumen, reported in the literature (Evans, 1981; Jilg, 1982).

In Expt 4 (Table 7) IVDN values were close to in vivo degradabilities when incubations 
Table 9. In vitro-degradable nitrogen (IVDN) for $24 \mathrm{~h}$ incubations derived from four extreme measurements (two with $200 \mathrm{mg}$ starch and two without starch), compared with IVDN values derived from regressions in Table 4, including all measurements (n 5-11)

\begin{tabular}{|c|c|c|c|c|}
\hline \multirow[b]{3}{*}{ Feedingstuff } & \multicolumn{4}{|c|}{ IVDN values calculated from: } \\
\hline & \multicolumn{2}{|c|}{ Extreme measurements } & \multicolumn{2}{|c|}{ All measurements } \\
\hline & $n$ & IVDN $_{24}^{*}$ & $n$ & IVDN $_{24}$ \\
\hline Casein & 4 & 1.01 & 10 & 0.99 \\
\hline Soya-bean meal & 4 & 0.95 & 8 & 0.94 \\
\hline Rape-seed meal & 4 & 0.83 & 10 & 0.84 \\
\hline Hay & 4 & 0.42 & 6 & 0.38 \\
\hline Feather meal & 4 & $0 \cdot 18$ & 8 & $0 \cdot 17$ \\
\hline Casein & 4 & $1 \cdot 00$ & 11 & $1 \cdot 03$ \\
\hline Linseed-cake meal & 4 & 0.83 & 8 & 0.85 \\
\hline Kapok residue & 4 & 0.68 & 11 & 0.69 \\
\hline Hay & 4 & $0 \cdot 34$ & 7 & 0.36 \\
\hline Maize-gluten feed & 4 & 0.64 & 5 & 0.64 \\
\hline
\end{tabular}

$$
\text { * IVDN }=\frac{A-\left(\frac{A-B}{C-D}\right) \times C-\left(\mathrm{NH}_{3}-\mathrm{N} \text { of blank }\right)}{\text { total } \mathrm{N} \text { of feedingstuffincubated }}
$$

$A$ is $\mathrm{mg} \mathrm{NH}_{3}-\mathrm{N}$ after $24 \mathrm{~h}$ incubation, when no carbohydrate is added; $B$ is $\mathrm{mg} \mathrm{NH}_{3}-\mathrm{N}$ after $24 \mathrm{~h}$ incubation, with carbohydrate added; $C$ is $\mathrm{ml}$ gas production in $24 \mathrm{~h}$, when no carbohydrate is added; $D$ is $\mathrm{ml}$ gas production in $24 \mathrm{~h}$, with carbohydrate added.

were stopped after $17 \mathrm{~h}$. The results indicate differences in the time-course of degradation of normal (rations 1, 3, 4 and 5) and protected proteins (ration 2). The latter reached only $60 \%$ of the value measured after $24 \mathrm{~h}$ within $8 \mathrm{~h}$, whereas normal proteins reach $80 \%$ and more of the final value within $8 \mathrm{~h}$. It may not be justified, therefore, to express protein degradability in vitro as a rate-constant to be adjusted to different retention times by a general function. We need to know the mean retention time of the feedingstuff in question, as a function of ration composition, level of feeding and animal characteristics, to be able to choose the appropriate incubation time for in vitro degradability studies. Further experiments must show whether factors other than incubation time cause marked differences between in vivo and in vitro determinations of protein degradation in the system used.

The ratio, substrate:inoculum was rather low (maximum $350 \mathrm{mg} \mathrm{DM}$ in $10 \mathrm{ml}$ rumen fluid $+20 \mathrm{ml}$ medium), thus $\mathrm{pH}$ did not fall below 6.2 in $24 \mathrm{~h}$ and accumulation of end-products of fermentation did not reach a critical level. At the end of incubation a dense population of protozoa could still be observed under the microscope, indicating a normal anaerobic fermentation. Lactic acid and hydrogen were present in traces only. The system tolerates up to $2 \mathrm{ml}$ oxygen, introduced into the syringe at the beginning of incubation (Steingass, 1983), provided contamination with $\mathrm{O}_{2}$ has been avoided when the rumen fluid is taken and the medium is $\mathrm{CO}_{2}$-saturated before mixing with the rumen fluid.

For IVDN calculation from regressions, triplicates of samples with four levels of carbohydrate and a blank have to be incubated; in total, fifteen syringes. A reduction in the number of syringes to be used for one determination seems possible, when taking into consideration that the factors of the regression equations are much more affected by extremes (with and without a maximum of starch) than by measurements in between. When these extremes are used for the calculation of protein degradation, the results are close to these IVDN values derived from regression equations in Table 4 with up to eleven single incubations (Table 9). 
The authors gratefully acknowledge the support given by Professor K. Rohr and Dr M. Brandt, FAL-Braunschweig, for providing samples of feedingstuffs for the ${ }^{15} \mathrm{~N}$-experiments.

\section{REFEREN CES}

Brandt, M. (1979). Versuche zur Quantifizierung der mikrobiellen Proteinsynthese im Pansen (mit Hilfe von ${ }^{15} \mathrm{~N}$ ) bei Verwendung harnstoffhaltiger Rationen. PhD Thesis, University of Kiel.

Brandt, M. \& Rohr, K. (1981). Zeitschrift für Tierphysiologie, Tierernährung und Futtermittelkunde 46, 39-48.

Brandt, M., Rohr, K. \& Lebzien, P. (1981). Zeitschrift für Tierphysiologie, Tierernährung und Futtermittelkunde 46, 49-59.

Bremner, I. (1965). In Methods of Soil Analysis, Part 2, no. 9 in the series Agronomy, pp. 1179-1206 [C. A. Black, editor]. Madison, Wisconsin: American Society of Agronomy, Inc.

Cafantaris, B. (1981). Über die Wirkung von Antibiotikazusätzen auf die mikrobielle Gärung im Pansensaft in vitro. PhD Thesis, University of Hohenheim.

Chamberlain, D. G. \& Thomas, P. C. (1979). Proceedings of the Nutrition Society 38, 138A.

Crooker, B. A., Sniffen, C. J., Hoover, W. H. \& Johnson, L. L. (1978). Journal of Dairy Science 61, $437-447$.

Evans, E. (1981). Canadian Journal of Animal Science 61, 91-96 and 97-103.

Harrison, D. G. \& McAllan, A. B. (1980). In Digestive Physiology and Metabolism in Ruminants, pp. 205-226 [Y. Ruckenbush and P. Thivend, editors]. Lancaster: MTP Press.

Hespell, R. B. \& Bryant, M. P. (1979). Journal of Animal Science 49, 1640-1659.

Hume, I. D. (1975). In Tracer Studies on NPN for Ruminants, vol. 2, pp. 1-6. Vienna: International Atomic Energy Authority.

Jarrige, R., Journet, M. \& Vérité, R. (1978). In Alimentation des Ruminants, pp. 117-118. Versailles: INRA Publications.

Jilg, T. (1982) Diplomarbeit, Fak. IV, University of Hohenheim.

Ling, J. R. \& Buttery, P. J. (1978). British Journal of Nutrition 39, 165-179.

McMeniman, N. P., Ben-Ghedalia, D. \& Elliot, R. (1976). British Journal of Nutrition 36, 571-574.

Mathers, J. C. \& Miller, E. L. (1981). British Journal of Nutrition 45, 587-604.

Menke, K. H., Raab, L., Salewski, A., Steingass, H., Fritz, D. \& Schneider, W. (1979). Journal of Agricultural Science, Cambridge 93, 217-222.

Naumann, K., Bassler, R., Seibold, R. \& Barth, K. (1976). In Methodenbuch vol. 3, method no. 7.2.3. [Verband landwirtshcaftlicher Untersuchungs und Forschungsanstalten, editor]. Melsungen: Neumann-Neudamm.

Ørskov, E. R. \& McDonald, I. (1979). Journal of Agricultural Science, Cambridge 92, 499-503.

Ørskov, E. R. \& Mehrez, A. Z. (1977). Proceedings of the Nutrition Society 36, 78A.

Pilgrim, A. F., Gray, F. V., Weller, R. A. \& Belling, C. G. (1970). British Journal of Nutrition 24, 589-598.

Raab, L. (1980). Untesuchungen über den Proteinabbau und die Proteinsynthese im künstlichen Pansen. PhD Thesis, University of Hohenheim.

Salewski, A., Seibold, C. \& Fröschle, H. (1974). Landwirtschaftliche Forschung 27, 112-119.

Siddons, R. C., Beever, D. E., Nolan, J. V., McAllan, A. B. \& MacRae, J. C. (1979). Annales de Recherche Vétérinaires 10, 286-287.

Steingass, H. (1983). Bestimmung des energetischen Futterwerts von wirtschaftseigenen Futtermitteln aus der Gasbildung bei der Pansenfermentation in vitro. PhD Thesis, University of Hohenheim.

Van Nevel, C. J. \& Demeyer, D. I. (1977). British Journal of Nutrition 38, 101-1 14.

Walker, D. J. \& Nader, C. J. (1975). Australian Journal of Agricultural Research 26, 689-698. 